\title{
Teat traumatization in conventional and automatic milking system
}

\author{
by P.Kunc*, I.Knížková*, J.Hanusová ** \\ * Institute of Animal Science, Livestock Technology and Management, Přátelství 815, 10400 Praha - \\ Uhříněves, Czech Republic, kunc.petr@vuzv.cz \\ ** Slovak University of Agriculture in Nitra, Faculty of Engineering, Department of Production Engineering, \\ Faculty of Engineering, Tr. A. Hlinku 2, 94976 Nitra, Slovak Republic, jankakoniarovce@gmail.com
}

\begin{abstract}
The aim of study was to evaluate teat traumatization caused by two milking system (CMS - conventional milking system, AMS - automatic milking system). IRT method was used for the evaluation. The stables with AMS and CMS (tandem milking parlour) were included in the monitoring. The vacuum level was $42 \mathrm{kPa}$ in both systems. Teat surface temperature was measured immediately before and after milking. The study showed that AMS had caused an insignificant increase of the teat temperature during milking compared to CMS. IRT can be recommended as a method that can produce important information about milking process.
\end{abstract}

\section{Introduction}

Automatic milking systems (AMS) became commercially available in the early 1990 [1]. Opinions on this new milking technology vary among farmers, experts and researchers [2]. Generally, milking is an important process in farming. Various milking routines, and the very fact of using machine milking, can affect the health and welfare of animals because an extremely sensitive organ, i.e., the mammary gland, comes into direct contact with the milking machine in this process. The teats are the most stressed part of the udder, because milking changes their condition. Repeated teat compressions may cause mechanical and circulatory changes in teat tissues and hyperaemia in the teat wall [3 - 5]. Such changes may even lead to pathological traumatisation manifested by, for example, congestion, oedema etc. There are a number of factors in milking that influence the condition of the teats. Literary sources emphasise the importance of the milking vacuum, and also the pulsation rate, pulsation ratio and the quality of the teat cups. Assessment of the teats and udder before and after milking usually based on visual observations [6]. Although IRT is applied less frequently in the study of the milking process, recent results show the potential of this measuring method. Generally, IRT is a suitable tool for early detection and screening for mastitis, and can also be useful for studying and evaluating the effects of various milking techniques on the teats and udders [6].

The aim of study was to evaluate teat traumatization caused by two milking system (CMS - conventional milking system, AMS - automatic milking system).

\section{Material and methods}

The measurements were done in two dairy farms. First farm was equipped with conventional milking system (CMS, tandem milking parlour, $2 \times 5$ milking stalls, milking process twice per day), second farm was equipped with automatic milking system (AMS, milking robot, dairy cows milked voluntarily). The vacuum level was $42 \mathrm{kPa}$ in both systems. Totally, 30 dairy cows (udders respectively) were measured in every milking system. Teat surface temperature was measured immediately before (premilking) and after milking (postmilking).

An IRT camera (FLIR SC660, FLIR systems, Inc.) was used for taking thermograms of the teats at a horizontal distance about $0.5 \mathrm{~m}$ away from the udder. The camera parameters were set to 0.97 for emissivity. FLIR Reporter Professional software (FLIR System Inc., 2010) was used for evaluation of thermograms. The differences in temperature of the teats were processed statistically (Statistica.cz (StatSoft, USA), ANOVA, POST-HOC Tukey test).

\section{Results}

Temperature situation is documented by figure 2 - 3. Immediately after milking the teat temperature increase was recorded in both systems. The lower teat temperature raising $(1.62 \mathrm{~K})$ was found out in AMS compared to CMS (1.8 $\mathrm{K})$. These temperature changes are shown in figure 1. But the difference in temperature increase between CMS $s$ and AMS were insignificant statistically. 


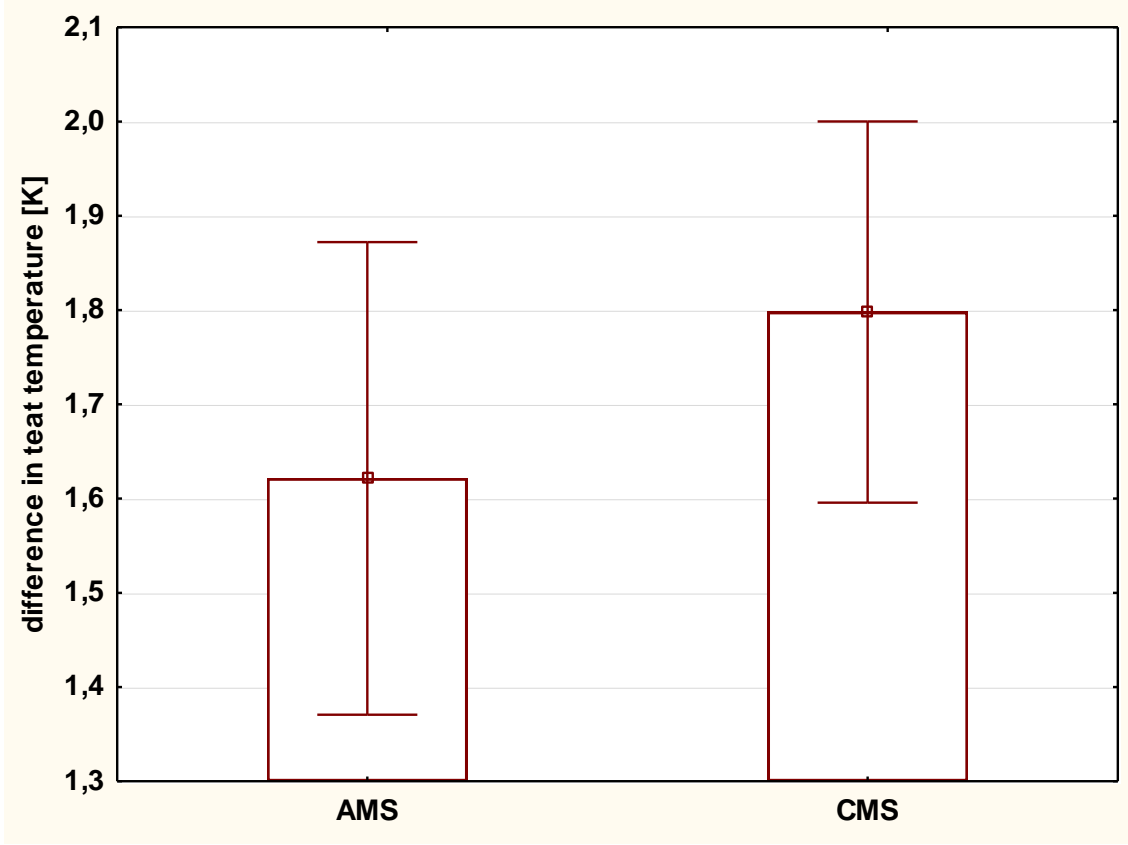

Fig 1. The changes of teat temperature (the differences postmilking - premilking) depending on milking system

\section{Discussion}

In general, the results show that the milking process is increasing teats temperature. This situation was described by [7 - 11] in conventional milking systems. Author [12] reports that the teats temperature is increasing about $2^{\circ} \mathrm{C}$ after milking in commonly used milking system. The difference of teat temperature before milking and after depended on using vacuum level [13]. In our study the temperature increase was also recorded in both milking systems. But the difference of temperatures before and after milking was insignificantly lower in automatic milking system than conventional milking system.

\section{Conclusion}

The measurements showed that AMS had not a negative influence on the mammary gland (the teats respectively) of dairy cows compared to CMS. It can be concluded that AMS is "friendly" to the udder of dairy cows. IRT can be recommended as a method that can produce important information where the possibilities of conventional diagnostic techniques have been exhausted. There are, however, certain limitations and factors that must be considered when using IRT in animals.

\section{Acknowledgements}

This study was supported by the project MZE RO0718. The experiment conducted with animals complies with the current laws of the country in which they were performed. 
10.21611/qirt.2018.p4

$14^{\text {th }}$ Quantitative InfraRed Thermography Conference, 25 - 29 June 2018, Berlin, Germany

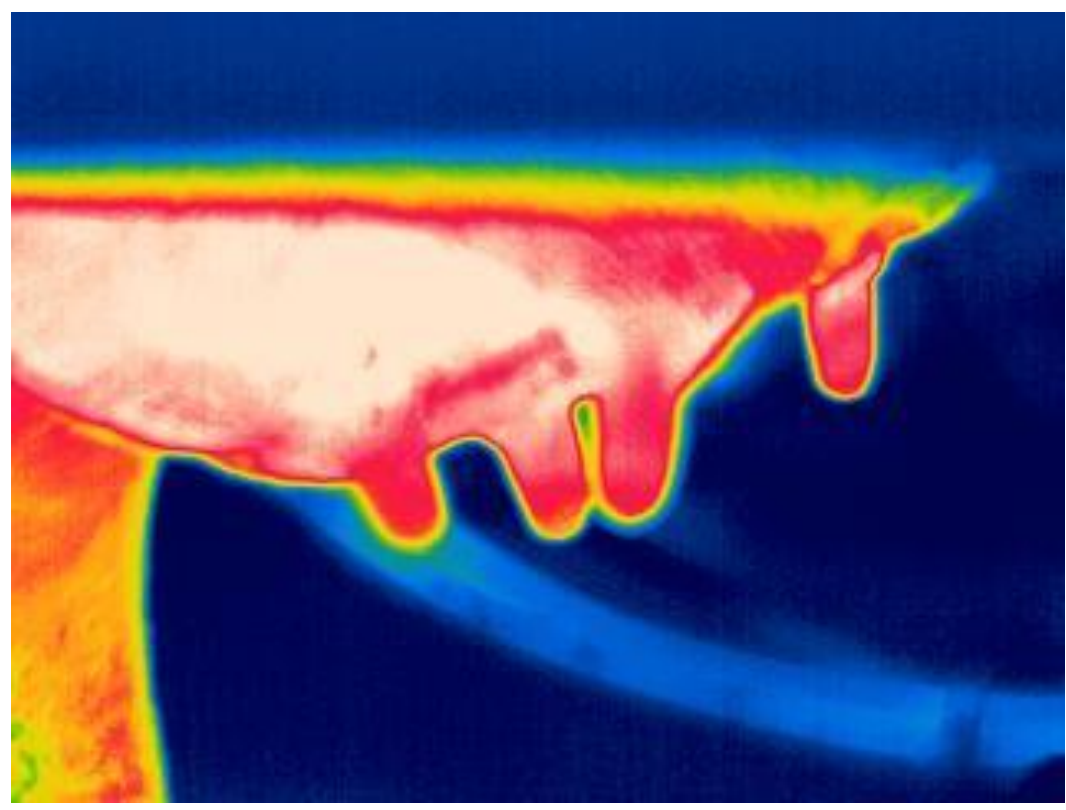

Fig. 2. The example of thermal profile of teats (AMS) - premilking

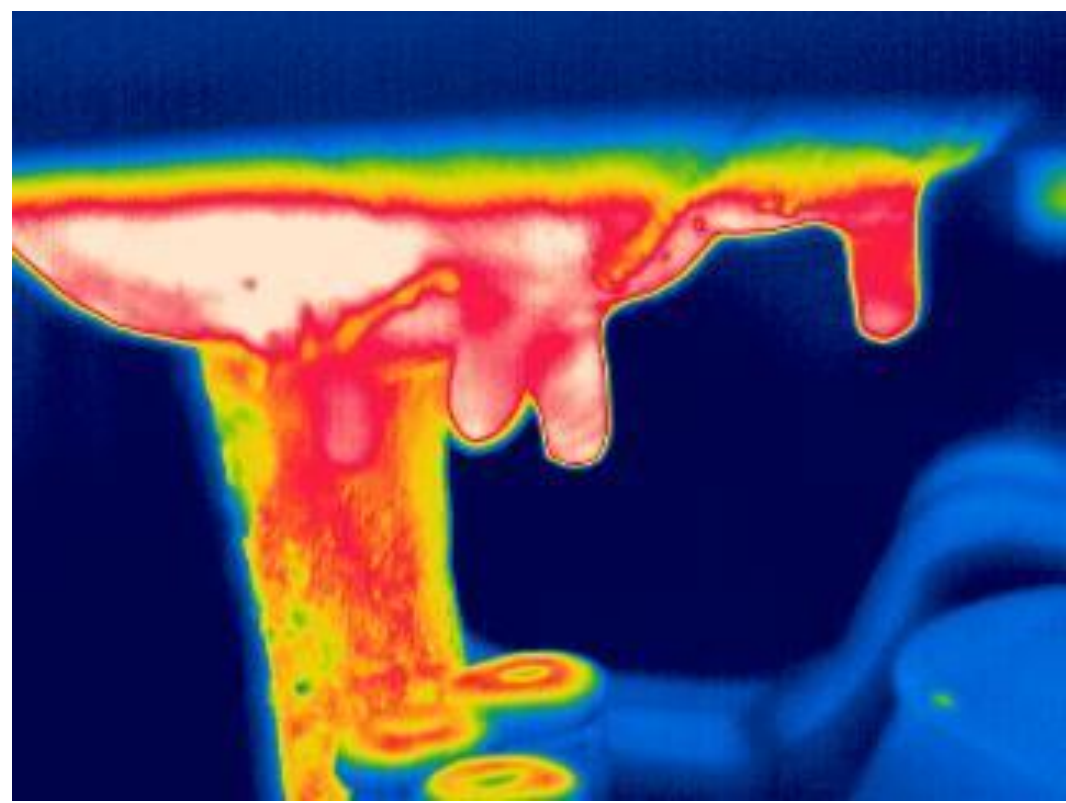

Fig. 3. The example of thermal profile of teats (AMS) - postmilking 


\section{REFERENCES}

[1] Salfer JA., Minegishi K., Lazuras. W-. et al., Finances and returns for robotic dairies. Journal of Dairy Science; 100: pp. $7739-7749,2017$.

[2] Ševčík J., Falta D., Somerlíková K., et al., Comparison conventional and automatic milking systems an extreme conditions by thermographic method. Acta Technologica Agriculturae; 4: pp. 96-100, 2016.

[3] Isaksson A., Lind O.. Teat reactions in cows associated with machine milking. Journal of Veterinary Medicine; 39: pp. 282-288; 1992.

[4] Burmeister JE., Fox LK., Hillers J., et al.. Effect of premilking and postmilking teat disinfectants on teat skin condition. Journal of DairyScience; 81:pp. 1910-1916, 1998.

[5] Zecconi A., Hamann J., Bronzo V., et al., Relationship between teat tissue immune defences and intramammary infections. Advances in Experimental Medicine and Biology; 480: pp. 287-293, 2000.

[6] Kunc P., Knížková I., "The Use of infrared thermography in livestock production and veterinary field." Infrared Thermography Recent Advances and Future Trends. University of Naples Federico II,: Bentham eBooks: pp. 84 $-101,2012$.

[7] Eichel H. Temperature of teat skin in dairy cows milked in piped milking parlor. Monatshefte fur Veterinarmedizin 1992; 47: pp. 193-5.

[8] Kunc P, Knizkova I, Koubkova M. The influence of milking with different vacuum and different design of liner on the change of teat surface temperature. Czech Journal of Animal Science; 44: 131 - 134, 1999.

[9] Barth K., Basic investigations to evaluate a highly sensitive infrared-thermograph-technique to detect udder inflammation in cows. Milchwissenschaft; 55: pp. 607-609, 2000.

[10] Kunc P., Knizkova I., Koubkova M., Flusser J., Dolezal O., Machine milking and its influence on temperature states of udder. Czech Journal of Animal Science; 45: pp. 1-15, 2000.

[11] Paulrud O., Clausen S., Andersen PE., et al., Infrared thermography to evaluate milking induced alterations in teat tissue fluid circulation. Journal of Animal Science; 80: pp. 80, 2000.

[12] Hamann J. Stimulation and teat tissue reaction. Kieler Milchwirtschaftlich Forschungsberochte; 44: pp. 339 47. 1992.

[13] HanusováJ., Gálik R., Bod'o Š., et al., Analysis of quality milking process vy thermographic method. Acta Universitatis Agriculturae et Silviculturae Mendelianae Brunensis; 64: pp. 1149 - 1153, 2016. 